\title{
EVALUATION OF SOME NON-TRADITIONAL PESTICIDES AGAINST THE TWO POD BORERS Helicoverpa armigera AND Etiella zinckenella POPULATION INFESTING COWPEA IN THE NEWLY RECLAIMED REGIONS \\ Abdou, Gehan Y. and E.F. Abdalla. \\ Pest and Plant Protection Dep. National Research Centre. Dokki, Egypt.
}

\section{ABSTRACT}

The two pod borers Helicoverpa armigera Hubner and Etiella zinckenella Treitschke are the most destructive insect pests which infest several crops of leguminosae in Egypt. Field experiments were conducted to evaluate the efficacy of some relatively safe compounds beside the conventional pesticides for control of these pests on cowpea, Vigna ungiculata under the conditions of newly reclaimed regions.

The results revealed that most of the treatments were able to suppress the levels of infestation to different degrees according to the nature of the tested compounds and the number of sprays applied. Application of non-traditional compounds such as thiamethoxam (neonicotinoid group) or Indoxacarb (oxadiazine group) significantly reduced the larval populations of $\mathrm{H}$. armigera by 76 and $70 \%$ and $E$. zinkenella by 58 and $55 \%$, respectively. Plots sprayed with methoxyfenozide (non-steroid ecdysone agonist )provided satisfactory control (60\% reduction) against $H$. armigera population while exerted weak activity $(<26 \%)$ against $E$. zinkenella population.

On the other hand, the potency of the common neurotoxic pesticides; chlorpyrifos (organophosphate) or cypermethrin (pyrethroid) were still the most effective pesticides against both species giving $76-81 \%$ reduction in infestation.

However, all the tested pesticides and the rates used had low residual effect against the two insects and thus, weekly applications to protect the plants of new insect attack were necessary. The treatments received six applications, throughout the entire season, effectively contained the damage caused by pest population more than those received four or two applications.

At harvest, high grain yield was obtained in the plots treated 6 times with the tested compounds. In general, Chlorpyrifos was the superior compound being registered $(45.9 \%)$ increase in yield over the untreated control value, followed by Thiamethoxam (41.6\%), Indoxacarb (39.0\%), Cypermethrin (38.8\%) then Methoxyfenozide $(33.9 \%)$. Moreover, remarkable elevation in the percentages of damaged grains ( 28.0\%) was recorded in all treatments sprayed twice throughout the season, while the corresponding values in those received 6 applications were restricted within $13.6-16.4 \%$.

The effectiveness and moderate persistence of such new compounds, beside their low mammalian toxicity make them promising agents when used alone or with other control measures on cowpea plantations.

\section{INTRODUCTION}

Cowpea Vigna unguiculata $(L)$ plants are subjected to attack by several insect pests, the most serious of which is the bean pod borer Etiella zinckenella (Olandiran and Oso, 1985 and Abdallah et al, 1994). The other pod borer Helicoverapa armigera has been recently observed at increasing numbers, in cowpea cultivated in the newly reclaimed parts of the desert. 
The damage of $H$. armigera usually occurs predominantly on young undeveloped pods whereas E. zinckenella fed on seeds only (Van Den Berg et al, 1998). Thus, the whole pods are destroyed during the crop's reproductive stage resulting considrable loss of yield at harvest (Sukul et al, 1989).

Field applications of several organophosphorous and pyrethroid pesticides had demonstrated their efficacy and residual activity for controlling the pod borers in cowpea cultivations (Abo El-Ghar et al, 1994 and Bachatly et al, 2002). However , the widespread use of the traditional insecticides, their toxic residues and hazard impacts on the environment encourage many researchers to explore new but effective compounds as safe alternatives for pest control (Dhadialla et al., 1998 and Tomizawa and Casida, 2003).

The present study was conducted to evaluate the insecticidal efficiency of some relatively safe compounds beside the conventional pesticides for control of the two pod borers and their subsequent effects on grain yield obtained.

\section{MATERIALS AND METHODS}

Field experiments were laid out in an area of about $1 / 2$ feddan cultivated with cowpea plants var. Kafr El - sheeh at Nubaria region , Beheira Governorate; where sandy loam soil type was dominant. Seeds growing took place on May 13, 2005 ; drip irrigated and most cultural methods were followed as commonly practiced. Plants when fully established, where thinned down to 1 plant /stand. A randomized block design incorporated 3 replicates of each treatment including untreated control. Each replicate (plot) was $6 \times 7 \mathrm{~m} \mathrm{(1/100} \mathrm{fed.)}$ and about $1 \mathrm{~m}$ planted area was left around each plot to avoid any insecticide drifts.

\section{Pesticide treatments and yield assessments :}

The tested pesticides and their recommended rates of application are shown in table (1).

Table (1): The tested pesticides and their rates of application :

\begin{tabular}{|l|c|c|c|c|}
\hline \multicolumn{1}{|c|}{ Common name } & Trade name & Chemical group & $\begin{array}{c}\text { Rate of use/100L } \\
\text { (recommended) }\end{array}$ & $\begin{array}{c}\mathbf{L D}_{50} \text { for } \\
\text { rats } \\
(\mathbf{m g} / \mathbf{k g})\end{array}$ \\
\hline Thiamethoxam & $\begin{array}{c}\text { Actara 25\% } \\
\text { WG }\end{array}$ & Neonicotinoid & $20 \mathrm{gm}$ & 1563 \\
\hline Indoxacarb & $\begin{array}{c}\text { Avaunt } \\
15 \% \text { SC }\end{array}$ & Oxadiazine & $26.3 \mathrm{gm}$ & 1732 \\
\hline Methoxyfenozide & $\begin{array}{c}\text { Runner } \\
24 \% \text { SC }\end{array}$ & Diacylhydrazine* & $37.5 \mathrm{ml}$ & $>5000$ \\
\hline Chlorpyrifos & $\begin{array}{c}\text { Chlorzan } \\
48 \% \text { EC }\end{array}$ & Organophosphate & $250 \mathrm{ml}$ & 149 \\
\hline Cypermethrin & $\begin{array}{l}\text { Slabeed } \\
30 \% \text { EC }\end{array}$ & Pyrethroid & $50 \mathrm{ml}$ & 250 \\
\hline
\end{tabular}

* Non-steroid ecdysone agonist

Weekly samples (10 pods/plot) were randomly collected during the reproductive growth stage , examined in the laboratory and when the average 
numbers of larvae of $H$. armigra and $E$. zinckenella considerably increased (3.0-4.6 larvae 10 pods), the pesticides were applied. For each compound, spraying was conducted 2 , 4 , or 6 times throughout the reproductive stage. The first spray started on July 26, 2005 and the other sprays were followed at weekly intervals. A knapsack sprayer $20 \mathrm{~L}$ capacity was used in applying the tested compounds as foliar treatments, dilute with water at the rate of $400 \mathrm{~L}$ water/fed.

Regular samples were collected weekly just before the next spray, examined, recorded and the percent reduction in larval infestation of each species was calculated according to Henderson and Tilton formula (1955).

At harvest, five random plants were labelled in each plot, where the pods were picked twice at 10 days apart. The harvest pods air dried, the grains were separated and sorted (intact and damaged) and their weights per 5 plants were determined. The data were analyzed by the analysis of variance (A NOVA) and Duncan's multiple, range (Snedecor, 1970).

\section{RESULTS AND DISCUSSION}

A). Effect of the tested compounds on $\boldsymbol{H}$. armigera infestation :

The average number of larvae/replicate and percent of reduction in infestation are presented in table( 2).

The results showed that most of the chemical treatments were able to suppress the levels of infestation to different degrees in comparison to that of untreated control. The suppression, however, greatly varied according to the nature of the tested compound and the number of sprays applied .

In the $1^{\text {st }}$ week after spraying, where all the plots were treated once, the non-traditional compounds; thiamethoxam and indoxacarb displayed over $70 \%$ reduction in infestation, meanwhile the non steroid ecdysone agonist, methxoyfenozide exhibited moderate control (61\% reduction). In the meantime the common neurotoxic pesticides chlorpyrifos and cypermethrin significantly reduced the larval content much more the new compounds and can protect the pods, from new insect attack giving $79-83 \%$ reduction in infestation. The same trend of results was also observed in the $2^{\text {nd }}$ inspection. Ahmad et al, (2003) evaluated the toxicity of new chemistries viz. fipronil, indoxacarb, and emamectin benzoate against field populations of $H$. armigera, which were highly resistant to conventional chemistries. They found that the majority of population exhibited susceptibility close to the baseline data. They concluded that such new compounds can restore the profitability of crop protection by countracting and preventing insecticide resistance in $H$. armigera, populations.

The present results also indicated that, the reduction in infestation obtained in the $3^{\text {rd }}$ and $4^{\text {th }}$ inspections varied according to number of sprays applied. The larval population of $H$. armigera depressed more when the tested compounds were applied 4 times (treatments B) than those applied twice (treatments A). The reduction in infestation amounted to be 53 and $55 \%$ when thiamethoxam was applied twice compared to 78 and $100 \%$ in those received 4 times application, at $3^{\text {rd }}$ and $4^{\text {th }}$ inspections, respectively (table2). A similar pattern of efficiency was manifested in most corresponding treatments. The effectiveness of thiamethoxam and imidacloprid against 
Abdou, Gehan Y. and E.F. Abdalla.

several economic insects on a variety of crops including barley, cotton and corn as well as stored products are well documented (Lawson et a, 1999 and Yue et al , 2003).

Table (2): Efficacy of the tested pesticides against the pod borer $\boldsymbol{H}$. armigera on cowpea plants, Nubaria region.

\begin{tabular}{|c|c|c|c|c|c|c|c|c|c|c|c|c|}
\hline \multirow{2}{*}{\multicolumn{2}{|c|}{ Treatment }} & \multicolumn{11}{|c|}{$\begin{array}{l}\text { Avg. no. Larvae/10 pods (Percent reduction in infestation) as } \\
\text { indicated weeks after the first spray }\end{array}$} \\
\hline & & \multirow{2}{*}{\begin{tabular}{|c|}
$\begin{array}{c}\text { Pre-count } \\
\text { (just before } \\
\text { spraying) }\end{array}$ \\
5.6
\end{tabular}} & \multicolumn{2}{|c|}{1} & \multicolumn{2}{|c|}{2} & \multicolumn{2}{|c|}{3} & \multicolumn{2}{|c|}{4} & \multicolumn{2}{|c|}{$\begin{array}{l}\text { Overall } \\
\text { mean }\end{array}$} \\
\hline \multirow[t]{2}{*}{ Thiamethoxam } & $A$ & & 1.3 & (76) & 1.6 & (71) & 1.6 & (53) & 1.0 & (55) & 1.4 & $(64)$ \\
\hline & $B$ & 4.6 & 1.3 & (70) & 1.3 & (72) & 0.6 & (78) & 0.0 & $(100)$ & 0.8 & (80) \\
\hline \multirow[t]{2}{*}{ Indoxacarb } & $A$ & 4.6 & 1.3 & (70) & 1.6 & (65) & 1.6 & (43) & 1.6 & (12) & 1.5 & (48) \\
\hline & $B$ & 6.0 & 1.6 & (72) & 1.6 & (73) & 0.6 & (84) & 1.6 & (32) & 1.4 & (65) \\
\hline \multirow[t]{2}{*}{ Methoxyfenozide } & $A$ & 4.3 & 1.6 & (61) & 1.6 & (63) & 1.6 & (39) & 2.0 & $(0.0)$ & 1.7 & (41) \\
\hline & $\mathrm{B}$ & 3.6 & 1.3 & (62) & 1.3 & (64) & 1.0 & (54) & 1.3 & (8.0) & 1.2 & (47) \\
\hline \multirow[t]{2}{*}{ Chloropyrifos } & $A$ & 5.0 & 1.0 & (79) & 0.6 & (88) & 1.0 & (67) & 1.6 & (19) & 1.1 & (63) \\
\hline & $\mathrm{B}$ & 3.6 & 0.6 & (83) & 0.6 & (83) & 0.3 & (86) & 0.6 & (58) & 0.5 & (78) \\
\hline \multirow[t]{2}{*}{ Cypermethrin } & A & 3.3 & 0.6 & (81) & 0.6 & (82) & 1.0 & (50) & 0.0 & (100) & 0.7 & (78) \\
\hline & $\mathrm{B}$ & 3.3 & 0.6 & (81) & 0.6 & (82) & 0.3 & (85) & 0.0 & (100) & 0.4 & (87) \\
\hline Untreated & & 6.6 & 6.3 & - & 6.6 & - & 4.0 & - & 2.6 & - & 4.9 & - \\
\hline LSD at 0.05 & & 2.5 & 1.5 & & 1.2 & & 1.0 & & 1.1 & & 1.4 & \\
\hline
\end{tabular}

A= Received two applications.

$\mathrm{B}=$ Received four applications.

In the subsequent samples collected after the $4^{\text {th }}$ spray, several green pods were infested with $E$. zinckenella larvae, but no actual numbers of $H$. armigera, larvae were found any more, even in untreated plots. Such decline of the natural population may be attributed to the maturation of some cowpea pods as well as the relatives care of young undeveloped pods (Van Den Berg et al, 2000). Probably, the adult migration towards more preferable hosts surrounding the experimental region can not also be neglected.

$B)$. Effect of the tested compounds on E. Zinckenella infestation

The reduction percentages in larval infestation caused by different pesticide treatments are presented in Table (3).

The results showed gradual increase in the natural population (expressed as numbers of larvae/10 pods), throughout the whole experimental period (6 weeks).

In the meantime, most of the chemical treatments significantly reduced the incidence of the pod borer infestation shortly after spraying and thus different degrees of suppression were obtained. Thiamethoxam presented 58 and $63 \%$ reduction in infestation after one and two weeks of spraying while Indoxacarb displayed 55 and $67 \%$ reduction against $E$. Zinckenella population, repectively, table (3). However, the effects of the tested compounds (except methoxyfenozed), did not greatly differ of those obtained concerning the other lepidopterous insect $H$. armigera (Table 2).

The treatments were more recognized at $3^{\text {rd }}$ inspection and forth where pesticides were applied 2, 4, or 6 times throughout the season. A progressive increase in the larval population was observed in the successive samples collected from treatments A (where the plotes were received only 
twice sprays) table (3). This mean that the direct spray was able to affect the pod borer and protect cowpea plants for only two weeks after application and the insect population regained its vitality afterwards i.e. indicating short residual effects of the tested compounds.

Abo El-Ghar et al (1994): mentioned that the numbers of $E$. Zinckenella larvae found after 7 days of treatments of selected organophousphorous, carbamates and pyrethroids insecticides were significantly reduced by $>86 \%$ than those in the untreated plots. However , the IGRs applied alone , flufenoxuron , Dowco -439 or in mixtures methomyl / flufenoxuron and chorpyrifos / Dowco - 439 exhibited moderate levels in controlling the larvae through 21 days after the treatments.

Table (3): Efficacy of the tested pesticides against the pod borer $E$. zinckenella on cowpea plants, Nubaria region

\begin{tabular}{|c|c|c|c|c|c|c|c|c|c|}
\hline \multirow{2}{*}{\multicolumn{2}{|c|}{ Treatment }} & \multicolumn{8}{|c|}{$\begin{array}{c}\text { Avg. no. Larvae/10 pods (percent reduction in infestation) as indicated } \\
\text { weeks after the first spray }\end{array}$} \\
\hline & & 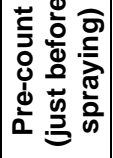 & 1 & 2 & 3 & 4 & 5 & 6 & $\begin{array}{l}\text { Overall } \\
\text { mean }\end{array}$ \\
\hline \multirow{3}{*}{\multicolumn{2}{|c|}{ Thiamethoxam }} & 3.6 & $2.3(58)$ & $2.0(63)$ & $3.0(53)$ & $5.3(27)$ & $7.6(17)$ & $10.0(15)$ & \begin{tabular}{|l|}
$5.0(38.8)$ \\
\end{tabular} \\
\hline & & 4.0 & $3.6(41)$ & $2.3(61)$ & $2.6(64)$ & $3.0(63)$ & $3.6(65)$ & $6.0(54)$ & $3.5(58.0)$ \\
\hline & & 5.6 & $4.3(50)$ & $3.0(64)$ & $2.6(74)$ & $2.6(77)$ & $3.6(75)$ & $5.3(71)$ & $3.6(68.5)$ \\
\hline \multirow[t]{3}{*}{ Indoxacarb } & A & 3.3 & $2.3(55)$ & $1.6(67)$ & $2.6(59)$ & $4.6(31)$ & 7.0 (17) & $8.6(20)$ & $4.5(41.5)$ \\
\hline & B & 4.6 & $3.6(49)$ & $2.6(62)$ & $3.0(63)$ & 2.6 & $5.3(55)$ & 8.0 & $4.2(58.0)$ \\
\hline & C & 5.3 & $3.6(55)$ & $2.6(67)$ & $3.3(65)$ & $3.6(72)$ & $4.0(70)$ & $6.3(64)$ & 3.8 (65.5) \\
\hline \multirow{3}{*}{$\begin{array}{l}\text { Methoxyfenoz- } \\
\text { ide }\end{array}$} & A & 3.6 & $5.6(0.0)$ & $3.6(33)$ & $5.3(18)$ & 6.0 & $7.6(17)$ & $9.6(18)$ & $6.3(17.3)$ \\
\hline & B & 4.3 & $6.3(5 . .0)$ & $4.0(37)$ & $6.0(22)$ & 6.0 & 9.0 (18) & $11.3(20)$ & 7.1 (22.2) \\
\hline & C & 3.3 & $4.6(9.0)$ & $3.6(26)$ & 3.6 (39) & $4.0(40)$ & 7.0 (17) & 7.3 & 5.0 \\
\hline \multirow[t]{3}{*}{ Chloropyrifos } & A & 4.6 & $1.6(77)$ & $1.6(77)$ & $3.3(60)$ & 6.0 & $8.3(29)$ & $10.3(31)$ & 5.2 \\
\hline & B & 3.3 & $1.6(68)$ & $1.3(73)$ & $1.6(73)$ & $1.6(76)$ & $3.0(64)$ & 7.0 & $2.7(64.8)$ \\
\hline & C & 4.6 & $2.3(67)$ & $1.0(85)$ & $2.3(72)$ & 2.0 & $2.6(78)$ & 3.0 & 2.2 \\
\hline \multirow[t]{3}{*}{ Cypermethrin } & A & 4.3 & $1.6(76)$ & $1.6(75)$ & $2.6(66)$ & 6.0 & $7.6(31)$ & $11.0(22)$ & 5.1 \\
\hline & B & 3.6 & $2.3(58)$ & $1.3(76)$ & $1.6(65)$ & $1.6(78)$ & $3.0(67)$ & 7.0 & $2.8(65.8)$ \\
\hline & C & 4.6 & $2.3(67)$ & $1.3(81)$ & $1.6(81)$ & 1.6 & $2.3(80)$ & 3.3 & 2.1 (78.3) \\
\hline Untreated & & 5.6 & & & & & $14.3-$ & 18.3 & $11.8-$ \\
\hline L.S.D at 0.05 & & 1.4 & 0.9 & 1.1 & 1.2 & 1.5 & 1.8 & 1.6 & 2.0 \\
\hline
\end{tabular}

$\mathrm{C}=$ Received six applications.

Similarly, the insect population of treatments $B$ raised with the time elapsed after spraying compared to those treated six times (treatments $C$ ). This confirm the previous results of short residual effects of the tested compounds. Such decline (short persistence) of the activity was manifested even in the conventional pesticides. The prevailing weather conditions of Nubaria region during July and August which exceeds $38{ }^{\circ} \mathrm{C}$ during the daytime 16 hrs. may play an important role in enhancing the compounds degradation.

In controlling the major insect pests (including $H$. amigera and $E$. zinkenella) of soybean in Thailand, Abdullah et al, (2001) concluded that better control and highest yield were achieved when applied cypermethrin at $0.0007 \%$, Azadirachtin at $0.1 \%$ or Delfin at 53.000 unit $/ \mathrm{mg}$ at 10 days 
interval until harvest.

C). Effect of the tested compounds on grain yield :

The data of grain yield $/ 5$ plants obtained after different insecticidal treatments are presented in table (4).

As mentioned before, most of the treatments suppressed the pest populations and thus, positive effects on the yield were gained compared to the unsprayed control. However the grain yield tended to be higher in plots sprayed 6 times than those received four or only two applications. In term of figures, $138.6,155.5$ or $173.5 \mathrm{gm}$ grain $/ 5$ plants were obtained where the insecticide thiamethoxam was sprayed 2, 4 or 6 times, respectively. Similar results were recorded with the other tested pesticides. Chlorpyrifos was the superior compound in this respect being registered $45.9 \%$ increase in the yield over the control value followed by thiamethoxam. (41.6\%), and indoxacarb (39\%), cypermethrin (38.8\%) then methoxyfenozide (33.9\%). Owatsakul (1998) reported that cyhalothrin L $2.5 \%$ EC at $20 \mathrm{~m} / 20 \mathrm{~L}$ and alphacypermathrin $10 \% \mathrm{EC}$ at $15 \mathrm{ml} / 20 \mathrm{~L}$ provided effective control of the limabean pod borer, the infested pods were about 14.5\% and 25.8\% respectively, compared to $77.4 \%$ in the untreated plots.

Since majority of the Egyptians often consume cowpea as dry grains after cooking, the incidence of the grain damage was considered in present study. The results in table (4), indicate remarkable elevation in the percentages of damaged grain in all treatments sprayed twice throughout the season.

Table (4): Effect of various insecticidal treatments on grain yield of cowpea plants.

\begin{tabular}{|c|c|c|c|c|c|c|}
\hline \multirow{2}{*}{\multicolumn{2}{|c|}{ Treatment }} & \multicolumn{3}{|c|}{ Avg. grain yield (gm/5 plants) } & \multirow{2}{*}{$\begin{array}{c}\% \text { increase over } \\
\text { control }\end{array}$} & \multirow{2}{*}{$\begin{array}{l}\% \text { damaged } \\
\text { grains }\end{array}$} \\
\hline & & Intact & Damaged & Total & & \\
\hline \multirow[t]{3}{*}{ Thiamethoxam } & $A$ & 103.6 & 35.0 & 138.6 & 13.1 & 25.3 \\
\hline & $\mathrm{B}$ & 134.5 & 21.0 & 155.5 & 26.9 & 13.5 \\
\hline & $\mathrm{C}$ & 148.5 & 25.0 & 173.5 & 41.6 & 14.4 \\
\hline \multirow[t]{3}{*}{ Indoxacarb } & $A$ & 98.8 & 46.2 & 145.0 & 18.4 & 31.9 \\
\hline & $\mathrm{B}$ & 116.0 & 28.5 & 144.5 & 17.9 & 19.7 \\
\hline & $\mathrm{C}$ & 142.3 & 28.0 & 170.3 & 39.0 & 16.4 \\
\hline \multirow[t]{3}{*}{ Methoxyfenozide } & $A$ & 96.4 & 35.6 & 132.0 & 7.8 & 27.0 \\
\hline & $\mathrm{B}$ & 108.5 & 33.5 & 142.0 & 15.9 & 23.6 \\
\hline & $\mathrm{C}$ & 126.5 & 37.5 & 164.0 & 33.9 & 22.9 \\
\hline \multirow[t]{3}{*}{ Chloropyrifos } & A & 94.6 & 42.0 & 136.6 & 11.5 & 30.7 \\
\hline & $\mathrm{B}$ & 115.8 & 29.6 & 145.4 & 18.7 & 20.4 \\
\hline & $\mathrm{C}$ & 150.2 & 28.6 & 178.8 & 45.9 & 16.0 \\
\hline \multirow[t]{3}{*}{ Cypermethrin } & A & 99.1 & 37.5 & 136.6 & 11.5 & 27.5 \\
\hline & $\mathrm{B}$ & 124.2 & 21.0 & 145.2 & 18.5 & 14.5 \\
\hline & $\mathrm{C}$ & 146.8 & 23.2 & 170.0 & 38.8 & 13.6 \\
\hline \multirow{2}{*}{\multicolumn{2}{|c|}{$\begin{array}{l}\text { Control } \\
\text { LSD at } 0.05\end{array}$}} & 88.2 & 34.3 & 122.5 & - & 28.0 \\
\hline & & 19.5 & 5.2 & 20.4 & & 3.4 \\
\hline
\end{tabular}

$\mathrm{C}=\mathrm{Received}$ six applications

Such effects, which related to high pest infestation, sometimes exceed the control value $(28.0 \%)$. On the other hand, in most treatments received 6 sprays, beside the high productivity gained, the reduction in the damaged grains was restricted within $13.6-16.4 \%$. 
In fact, the tested pyrethroid and organophosphate pesticides are prominent tools for control both insect species. However, the effectiveness and moderate persistence of such new compounds, beside their low mammalian toxicity make them promising pest control agents (Smagghe et al 1999 and Abdalla et al, 2005) .

It could be concluded that weekly applications of the promising compounds during podding and maturation stage of cowpea plants are necessary in controlling both $H$. armigera and E. Zinckenella populations. They also should be used in rotation with each other to reduce the possibility of resistance development.

\section{REFERENCES}

Abdalla, E.F.; El-Sayed, I.E.; Abdel-Lateef, M.F.; El-Samadisy, A.M. and Hassanein, A.M. (2005): Toxicity and action of some relatively safe compounds on the cotton leafworm Spodoptera littoralis (Boisd.) $\mathrm{J}$. Agric. Sci. Mansoura Univ., 30(3): 1655-1667.

Abdallah, S.A. Barakat, A.A.; Sammour, E.A. Badawy; H.M.A. and Soliman, M.M. (1994). Field evaluation of certain insecticides against cowpea pod borer Etiella zinckenella. Bull Ent. Soc. Egypt. Econ. Ser. 21: 191197.

Abdullah,M. Sarnthoy, O.; Isichaikul, S. and Tantakom, S. (2001): Efficacy of cypermethrin, Neem extract and Bacillus thuringiensis for controlling insect pests of vegetable soybean. Kasetsart J. (Nat. Sci.)35: 14-22.

Abo El-Ghar, G.E.S.; El-Sayed, A.M.; El-Shiekh, A.E. and Radwan, H.S.A. (1994): Field tests with insecticides and insect growth regulators to control insect pests of cowpea and its effects on certain beneficial insects. Arch. Phytopath. Pflanz. 28: 531-543.

Ahmad, M.; Arif, M.I. and Ahmad, Z. (2003): Susceptibility of Helicoverpa armigera (Lep., Noctuidae) to new chemistries in Pakistan . Crop Protection. 22: 539-544.

Bachatly, M.A. Hady S.A.; Hegab, M.F.A.H. and Kamel, M.H. (2002): Pesticidal activity of certain pesticides against the cowpea Pod borer Etiella zinckenella (Lepd., Pyralidae). J. Adv. Agric. Res. 7(2): 393-403.

Dhadialla, T.S.; Carlson, G.R. and Le, D.P. (1998). New insecticides with ecdysteroidal and juvenile hormone activity. Ann. Rev. Entomol. 43: 545-569.

Henderson, C.F. and Tilton, E.W. (1955): Tests with acaricides against the Brown wheat mite. J. Econ. Ent. 38: 157-161.

Lawson, D.S.; Dunbar, D.M.; White, S.M. and Ngo, N. (1999): Actara 25WG: control of cotton pests with a neonicotinoid insecticides, thiamethoxam. Proc. Beltwide. Cotton Conf. Memphis, Tenn 2: 1106-1109.

Olandiran, A.O. and Oso, B.A. (1985): Interactions between fungicides, insecticides and spraying regimes in the control of fungal diseases, insect pests and yield of cowpea Vigna unguiculata L. J. Agric. Sci. Comb. 105: 45-49.

Owatsakul, P. (1998): The biology of Limabean pod borer Etiella zinckenella in vegetable soybean and its chemical control. www.grad.cmu.ac.th/abstract/1998/agi/abstract/agi980052.htm

Smagghe, G.; Carton, B.; Wesemael, W.; Ishaaya, I. and Tirry, L. (1999): Ecdysone agoinsits-mechanism of action and application on Spodoptera species. Pestic. Sci. 55: 343-389.

Snedecor, G.W. (1970): Statistical methods applied to experiment in agriculture and biology ((lowa state press, U.S.A. 534pp). 
Sukul, P., Handa, S.K. and Singh, K.M. (1989): Comparative efficacy of synthetic pyrethroids against pod borer complex, corp. growth and yield of green Gram. Indian. J. Entomol. 49(3): 408-413.

Tomizawa, M. and Casida, J.E. (2003): Selective toxicity of neonicotinoids attributable to specificity of insect and mammalian nicotinic receptors. Ann. Rev. Entomol. 48: 339-364.

Van Den Berg, H.; Aziz, A. and Machrus, M. (2000): On-farm evaluation of measures to monitor and control soybean pod-borer Etiella zinckenella in East Java, Indonesia. Inter. J. pest Manag. 46(3): 219-224.

Van Den Berg, H.; Shepared, B.M. and Nasikin, N. (1998): Damage incidence by Etiella zinckenella in soybean in East Java, Indonesia. Inter. J. Pest Manag. 44(3): 153-159.

Yue, B.; Wilde, G.E. and Arthur, F. (2003): Evaluation of thiamethoxam and Imdiacloprid as seed treatments to control European corn borer and Indian meal moth (Lep., Pyralidae) larvae. J. Econ. Ent. 96(2): 503509.

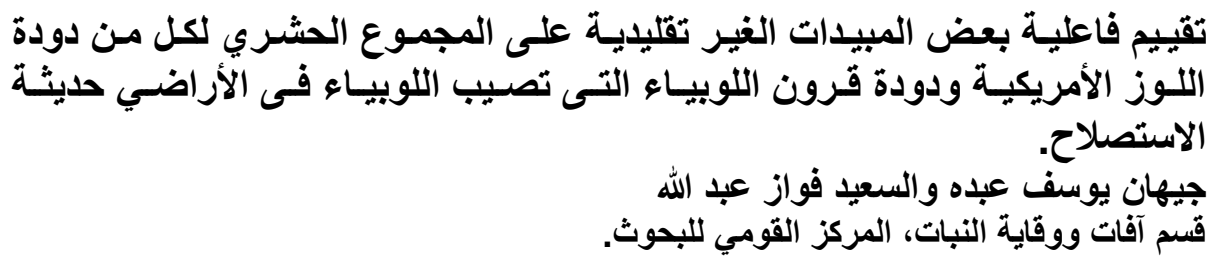

تعد حشرتا دودة اللوز الأمريكية Helicoverpa armigera Hubner ودودة قرون اللوبياء Etiella zinckenella Treitschke

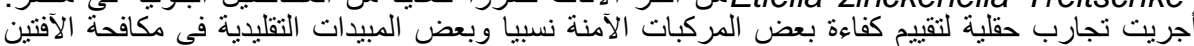
على اللوبياء تحت ظروف المت المناطق المسنصلحة حديثا.

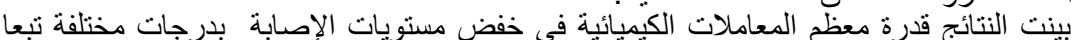

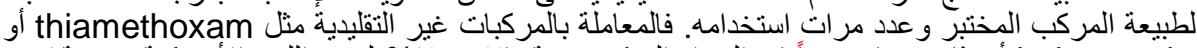

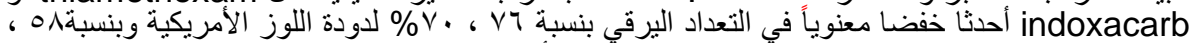

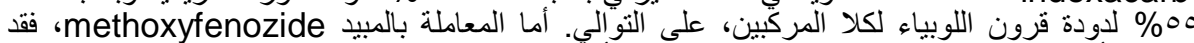

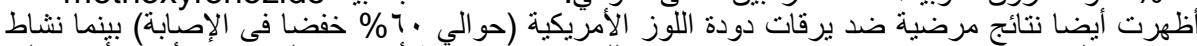

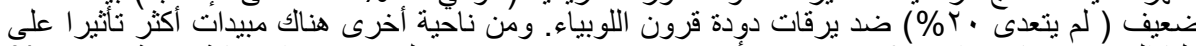

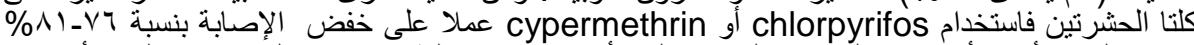

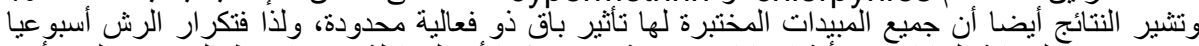

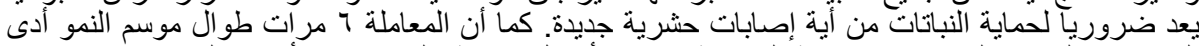

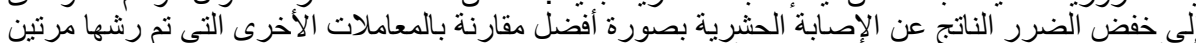

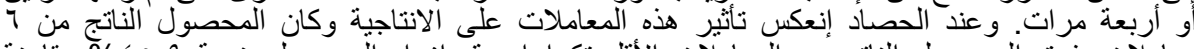

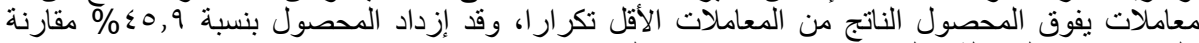

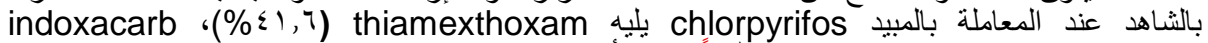

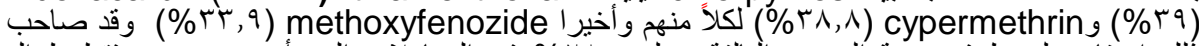

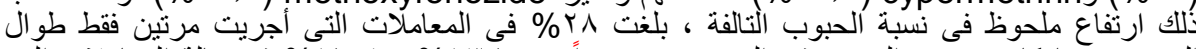

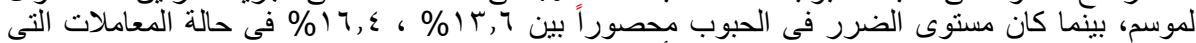

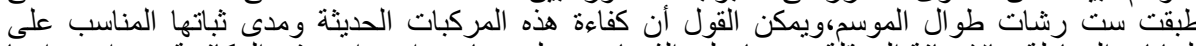

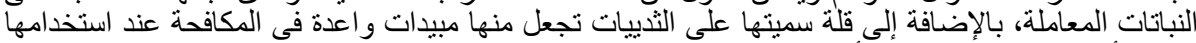
منفردة أو مع طرق الككافحة الآخرى على نباتات اللوبياء. 